\title{
THE DESTRUCTION OF RED CELLS BY ANTIBODIES IN MAN. III. QUANTITATIVE FACTORS INFLUENCING THE P.ATTERNS OF HEMOLYSIS IN VIVO *
}

\author{
By JAMES H. JANDL AND MANUEL E. KAPLAN $\dagger$ \\ (From the Thorndike Memorial Laboratory and Second and Fourth (Harvard) Medical \\ Services, Boston City Hospital, and the Department of Medicine, \\ Harvard Medical School, Boston, Mass.)
}

(Submitted for publication February 16, 1960; accepted March 18, 1960)

During the past several years it has become apparent through experimental studies with $\mathrm{Cr}^{51}$-labeled red cells that injured red cells are removed from the circulation in either of two general ways. In the first, altered red cells are selectively trapped in the spleen. Such splenic trapping can be induced by coating the cell surface with adherent proteins, as with incomplete agglutinins $(1,2)$ or metallo-protein complexes $(1,3)$, or by increasing red cell thickness, as when red cells are made spherocytic by exposure to heat (4) or to lecithin (5). In addition, immature red cells $(6,7)$ and red cells injured by "oxidant" drugs, such as acetylphenylhydrazine $(5,8)$ are preferentially, although not so avidly, sequestered by the normal spleen. When relatively small amounts of $\mathrm{Cr}^{51}$-labeled red cells are injected into man and the splenic filter remains "unsaturated," red cells coated by incomplete antibodies or rendered spherocytic in vitro are removed from the circulation by the spleen at a constant rate of approximately $3 \pm 1$ per cent per minute $(2,9)$, a rate which probably approaches the splenic blood flow. ${ }^{1}$ In some instances red cells so trapped in the spleen may be released subsequently into the circulation (5).

\footnotetext{
* This investigation was supported in part by Grant no. RG3507 (C7) from the National Institutes of Health, Bethesda, Md.

$\dagger$ Postdoctoral Research Fellow, Public Health Service.

1 Although no accurate data exist as to the blood flow of the normal human spleen, it can be roughly computed from knowledge of the hemoglobin content and blood mixing time. Since the normal spleen contains about $7 \mathrm{~g}$ of hemoglobin (10), or approximately 1 per cent of that of circulating blood, and since, according to Harris, McAlister and Prankerd (11), splenic "mixing" of normal $\mathrm{Cr}^{\text {s1 }}$-labeled red cells occurs within about 15 seconds, the normal splenic blood flow may be estimated to be approximately 1 per cent per 0.25 minute, or 4 per cent per minute.
}

In the second manner of red cell removal, more severe alterations of red cells are involved and the cells are sequestered diffusely throughout the reticuloendothelial system. Thus the liver, with its great mass, is the chief site of trapping. Such hepatic trapping ensues when red cells have been exposed to agglutinating antibodies $(1,2)$, complement-fixing antibodies $(12,13)$, agglutinating metallic cations $(1,3)$, sodium arsenate (4), and sterile incubation at $37^{\circ} \mathrm{C}$ for 24 hours or more (5). In general, these alterations involve either gross aggregation of red cells or a nearlytic injury to the cell membrane. When injected, small amounts of such cells are usually cleared rapidly, with half-disappearance rates of from 1.5 to 6 minutes. This presumably reflects the large blood flow of all the reticuloendothelial organs combined, among which the liver is foremost. In general, hepatic trapping of red cells kinetically resembles that of foreign particulate matter of many kinds. Although erythrophagocytosis may be provoked by some of the forms of red cell injury enumerated above, and although phagocytosis is often regarded as the essence of foreign particle clearance (14), phagocytosis is not visible during the initial stage in the hepatic trapping of red cells (15).

To what extent the contrasting pathways of red cell trapping outlined above are determined by qualitative, and to what extent by quantitative, factors is not certain. At least three purely quantitative factors are presumed to be involved: 1) the quantity of altered red cells present ; 2 ) the extent of the alteration; 3 ) the quantity of filtering (largely reticuloendothelial) tissue available (2). Although with respect to immune mechanisms, earlier studies had shown that the amount of antibody (anti-D) added to the appropriate (type D) red cells in vitro influenced the rate at which the 
affected cells were trapped by the spleen (2), it has not been ascertained whether quantitative differences in the extent of a given alteration might change the predominant pathway of red cell destruction from splenic to hepatic, or vice versa. At least two previous observations suggested, albeit inconclusively, that this might be the case. 1) Whereas on injection into a normal subject, type $\mathrm{D}$ red cells sensitized in vitro with anti-D were selectively trapped in the spleen, type $D$ red cells injected into immunized subjects whose plasma contained very high concentrations of anti-D were trapped to a moderate extent in the liver as well (2). 2) Although the liver is the major site of sequestration when type $\mathrm{B}$ ( or $\mathrm{A}$ ) red cells are injected into subjects with detectable complete antibodies against such cells, at least some subjects with agammaglobulinemia (i.e., extreme hypogammaglobulinemia) sequester ABOincompatible red cells in the spleen $(2,16)$.

There were inherent difficulties in the previous studies (2) of the quantitative effects of antibody added to red cells in vitro in terms of the subsequent fate of these cells in vitro; such studies involve a variable dissociation of antibody from the red cell after its injection into the circulation, the rate of this dissociation depending in part on the $\mathrm{D}$ antigen concentrations of the injected red cells and of the recipient's red cells. In order to explore quantitative factors influencing the effects of antibodies on red cells in vivo, the studies reported below were carried out in man and in rats.

\section{METHODS}

\section{Techniques applicable to studies in man}

Subjects. All studies relating to the effects of anti-B were carried out in a 56-year old woman with acquired agammaglobulinemia and less than $20 \mathrm{mg}$ per $100 \mathrm{ml}$ of gamma globulin in her serum. Previous studies (2) had shown that the patient, whose red cells were type A, possessed no anti-B which could be demonstrated in vitro, and that, as compared to their abrupt destruction in normal type A subjects, type B red cells were destroyed very slowly in the patient (half-survival time, 5 days), almost entirely in the spleen. Furthermore, after small weekly injections of type $B$ red cells had been given, labeled type $B$ red cells survived even longer (half-survival time, 22 days), suggesting ready exhaustion of a very small antibody pool. Relative to the studies conducted, this patient was regarded as possessing essentially no iso-antibody and as being suitable for passive immunization experiments.
Studies of the action of anti-D were conducted in one D-negative individual who had been specifically immunized against the $\mathrm{D}$ antigen at the Blood Grouping Laboratory, Boston, Mass., and in three elderly D-negative men who had no history of sensitization to the D antigen and whose sera contained no anti-D activity in vitro.

Techniques involiing donor red cells and antisera. In all studies of anti-B action, type $B$ red cells from the same individual were employed. Passive sensitization with anti-B was carried out by injecting aliquots taken from a single frozen specimen of serum ${ }^{2}$ containing anti-B obtained from an individual specifically hyperimmunized against the $\mathrm{B}$ antigen. In high concentrations in the presence of fresh serum complement, this serum hemolyzed type $B$ red cells; in saline it agglutinated a 5 per cent suspension of red cells to a titer of $1 / 200$, and rendered the cells agglutinable in polyvinylpyrrolidone (PVP) to a titer of $1 / 800$.

In all studies of anti-D action, type $\mathrm{D}$ red cells from the same individual were employed. Passive sensitization of the three D-negative subjects was accomplished as described below, by injecting aliquots taken from a single frozen specimen of plasma containing high concentrations of a nonagglutinating anti-D. This serum caused no agglutination of a 5 per cent suspension of type $\mathrm{D}$ red cells in saline at any concentration but rendered the cells agglutinable in PVP at antiserum dilutions of up to $1 / 16,000$ and in Coombs serum at antiserum dilutions of up to $1 / 1,000$. This anti-D serum was obtained from the same person who served as the actively immunized subject.

Techniques involving $C r^{51}$. In each experiment approximately $25 \mathrm{ml}$ of sterile whole donor blood was collected in siliconized screw-capped tubes containing $5 \mathrm{ml}$ of acid citrate dextrose (ACD) solution. To each was added $\mathrm{Cr}^{51}$ of high specific activity (200 to $300 \mu \mathrm{c}$ per $\mu \mathrm{g}$ ) in the form of $\mathrm{Na}_{2} \mathrm{Cr}^{51} \mathrm{O}_{4}{ }^{3}$ in amounts varying from 50 $\mu \mathrm{c}$, in the patient subjected to multiple studies, to $200 \mu \mathrm{c}$ in the subjects studied only once. After 30 minutes' gentle agitation at room temperature, the red cells were washed once in 10 to 15 volumes of sterile isotonic saline, were suspended in approximately 50 cent concentration in saline, a hematocrit reading was made, and an amount was injected which contained between 5 and 15 $\mathrm{ml}$ of packed red cells.

Peripheral blood from the injected subjects was obtained in a syringe containing one-tenth volume of 3 per cent sodium citrate. After mixing in test tubes, $3.0 \mathrm{ml}$ samples were removed for the determination of whole blood radioactivity. The remainder of these blood specimens were centrifuged at approximately 2,000 G; the supernatant plasma was removed and was respun at 2,000 $\mathrm{G}$ before $3.0 \mathrm{ml}$ samples were removed for measuring plasma radioactivity and plasma hemoglobin levels. Radioactivity of these materials was measured in a welltype scintillation counter and suitable correction factors

\footnotetext{
2 Generously provided by Dr. A. R. Jones of the Blood Grouping Laboratory, Boston, Mass.

3 Abbott Laboratories, Chicago, Ill.
} 
were applied for dilution of whole blood and of plasma by the anticoagulant.

Body surface radioactivity over the heart, liver and spleen of each subject was measured periodically as previously described (17). At the conclusion of each experiment a complete body scan was conducted seeking high concentrations of radioactivity in other areas. None such was found.

Method of study in vivo. In each experiment involving passive immunization the subject was first injected with the sample of $\mathrm{Cr}^{51}$-labeled, noncompatible red cells. For a period of 4 to 6 days the survival of these red cells and the subject's body surface radioactivity were followed. Then an amount of antiserum against the labeled cells, calculated to provide a desired ratio of antibody/red cells in the subject's circulation, was injected. During the subsequent several hours, numerous determinations of blood and corporeal radioactivity were made as illustrated in Figure 1. The acutely falling levels of red cell radioactivity after injection of antiserum were plotted on semilogarithmic paper, and the half-survival time was computed. The change in organ radioactivity was obtained by subtracting the relative radioactivity over each organ (17) just prior to antiserum injection from that measured after the cessation of the acute hemolytic process. The red cell trapping activity of the spleen relative to the liver $(\mathrm{S} / \mathrm{L})$ was then estimated by dividing the increment in splenic radioactivity by the increment in hepatic activity. An example of these calculations, as carried out in the experiment portrayed in Figure 1, is as follows:

$$
\begin{aligned}
& \Delta \mathrm{S}=\mathrm{S}_{\mathrm{a}}-\mathrm{S}_{\mathrm{b}}=1.95-1.35=0.60 \\
& \Delta \mathrm{L}=\mathrm{L}_{\mathrm{a}}-\mathrm{L}_{\mathrm{b}}=1.80-0.63=1.17 \\
& \mathrm{~S} / \mathrm{L}=\Delta \mathrm{S} / \Delta \mathrm{L}=0.60 / 1.17=0.51
\end{aligned}
$$

where $\Delta \mathrm{S}$ and $\Delta \mathrm{L}=$ increments in splenic and hepatic radioactivity, respectively, $S_{b}$ and $L_{b}=$ ratio of radioactivity spleen/precordium and liver/precordium, respectively, just before the injection of antiserum. $S_{\mathbf{a}}$ and $\mathrm{L}_{\mathrm{a}}=$ ratio of radioactivity spleen/precordium and liver/ precordium, respectively, after the cessation of the acute hemolytic process.

\section{Techniques applicable to studies in rats}

Subjects. The studies were made on large (400 to 500 g) males from a Bartonella-free strain (Charles River C. D.) of Sprague-Dawley rat.

Techniques involving donor red cells and antiserum. The rat red cells involved in each experiment were derived from fresh defibrinated blood obtained by cardiac puncture of normal animals of the same strain. Antiserum against rat red cells was obtained from a single adult male New Zealand rabbit which had received monthly intraperitoneal injections of saline-washed rat red cells for 8 months. Freshly drawn, this serum when incubated at $37^{\circ} \mathrm{C}$ with equal volumes of 5 per cent red cells in normal rat serum caused hemolysis to a titer of $1 / 100$, agglutination to a titer of $1 / 100$, and induced agglutinability in the presence of PVP to a titer of $1 / 8,000$ (Table II). After heating for 2 hours at $56^{\circ} \mathrm{C}$, the same antiserum in the presence of large volumes of fresh rat serum, caused hemolysis only when undiluted, agglutination to a titer of $1 / 100$, and agglutinability in PVP to a titer of $1 / 8,000$. All studies in vivo involved the use of aliquots taken from a single frozen specimen of this antiserum after it had been heated as described.

Techniques involving $C r^{51}$. Rat red cells were labeled by adding 20 to $30 \mu \mathrm{c}$ of $\mathrm{Cr}^{51}$ as $\mathrm{Na}_{2} \mathrm{Cr}^{51} \mathrm{O}_{4}$ per $\mathrm{ml}$ of defibrinated rat blood, and agitating gently for 30 minutes at room temperature. The blood was then centrifuged, the serum removed, and the red cells made up to 50 per cent by volume in isotonic saline preparatory to the addition of antiserum (see below).

Radioactivity in the circulating blood of rats was assessed on blood obtained from small terminal incisions in the rats' tails. Two $0.1 \mathrm{ml}$ samples were pipetted directly from the tail wound into test tubes suitable for use in a well-type scintillation counter. The first $0.1 \mathrm{ml}$ sample was added to a tube containing $1.0 \mathrm{ml}$ of heparinized water and was used to measure whole blood radioactivity. The second $0.1 \mathrm{ml}$ sample was added to heparinized saline. This suspension was then centrifuged and the supernatant decanted into a second tube for the counting of plasma radioactivity. Red cell radioactivity was determined as the difference between whole blood and plasma radioactivity.

The radioactivity of rat livers, spleens, lungs, kidneys, and femurs was also determined in a well-type scintillation counter as described elsewhere (7).

Method of study in vivo. To the saline suspension of $\mathrm{Cr}^{51}$-labeled rat red cells was added an equal volume of a predetermined dilution of antiserum. This mixture was incubated at $37^{\circ} \mathrm{C}$ with continuous gentle agitation for 1 hour, whereupon it was centrifuged, the plasma discarded, and the cells made up to a 50 per cent suspension in fresh rat serum for injection. Each rat was injected by tail vein with $0.5 \mathrm{ml}$ of labeled, antibody-treated red cells, and thereafter serial blood specimens were withdrawn by tail puncture. At approximately 2.5 hours the animals were sacrificed, and the various organs were weighed and counted.

Peripheral blood radioactivity as a percentage of injected $\mathrm{Cr}^{51}$ was calculated from the product of the $\mathrm{Cr}^{51}$ concentration and the estimated blood volume divided by the total injected dose. The blood volume in animals of this strain and size was shown by previous studies with $\mathrm{Cr}^{51}$-labeled normal red cells to be approximately 4.5 per cent of body weight. Organ radioactivity was calculated both as a percentage of injected $\mathrm{Cr}^{51}$ and as the concentration of $\mathrm{Cr}^{51}$ per wet weight.

\section{Miscellaneous techniques}

The presence of frank agglutination of red cells was determined by adding $0.1 \mathrm{ml}$ of cell suspension to $10 \mathrm{ml}$ of saline and examining microscopically a drop of the suspension. Increased red cell agglutinability was determined with PVP as described elsewhere (18). The presence of cell-adherent protein was determined by the technique of Coombs, Mourant and Race (19). Com- 
TABLE I

Influence of antibody/antigen ratio on the destruction of $C r^{51}$-labeled, type $B$ red cells by anti-B in a passively immunized patient with agammaglobulinemia

\begin{tabular}{|c|c|c|c|c|c|c|c|c|c|c|c|c|c|}
\hline \multirow{4}{*}{$\begin{array}{l}\text { Chrono- } \\
\text { logical } \\
\text { order of } \\
\text { experi- } \\
\text { ments }\end{array}$} & \multicolumn{2}{|c|}{$\begin{array}{l}\text { Red cells } \\
\text { injected }\end{array}$} & \multicolumn{3}{|c|}{ Antiserum injected } & \multicolumn{5}{|c|}{ Effect of antiserum in vivo } & & & \\
\hline & \multirow{3}{*}{$\begin{array}{l}\text { Initial } \\
\text { volume }\end{array}$} & \multirow{3}{*}{$\begin{array}{l}\text { Initial } \\
\text { half- } \\
\text { survival } \\
\text { time }\end{array}$} & \multirow{3}{*}{$\begin{array}{l}\text { Days } \\
\text { after } \\
\text { red } \\
\text { cell } \\
\text { injec- } \\
\text { tion }\end{array}$} & \multirow{3}{*}{$\begin{array}{l}\text { Volume } \\
\text { red } \\
\text { cells } \\
\text { present }\end{array}$} & \multirow{3}{*}{$\begin{array}{l}\text { Ratio } \\
\text { anti- } \\
\text { serum } \\
\text { red } \\
\text { cells }\end{array}$} & \multicolumn{3}{|c|}{ Red cell destruction } & \multicolumn{2}{|c|}{$\begin{array}{l}\text { Maximum } \\
\text { plasma } \mathrm{Cr}^{51}\end{array}$} & \multicolumn{3}{|c|}{$\begin{array}{l}\text { Sites of red cell } \\
\text { sequestration* }\end{array}$} \\
\hline & & & & & & & & & & & & & \\
\hline & & & & & & & & Rate & $\begin{array}{l}\text { Per cent } \\
\text { Cr } r^{51} \\
\text { injected }\end{array}$ & $\begin{array}{c}\text { Peak } \\
\text { time }\end{array}$ & $\Delta \mathrm{S}$ & $\Delta \mathrm{L}$ & $\mathrm{S} / \mathrm{L}$ \\
\hline & $m l$ & days & & $m l$ & & $\%$ & $m l$ & $\% / \min$ & & $\min$ & & & \\
\hline 3 & 11.9 & 9 & 6 & 7.3 & 0.01 & 23 & 1.8 & 1.1 & 0 & & 0.38 & 0.11 & 3.5 \\
\hline 5 & 14.8 & 11 & 6 & 11.7 & 0.02 & 40 & 5.9 & 3.7 & 0 & & 0.98 & 0.55 & 1.8 \\
\hline 2 & 9.3 & 15 & 5 & 6.9 & 0.07 & 87 & 6.0 & 13.9 & 0.2 & & 1.17 & 1.05 & $\begin{array}{l}1.0 \\
1.1\end{array}$ \\
\hline 1 & 7.8 & 10 & 4 & 5.1 & 0.59 & 100 & 5.1 & 34.7 & 8.6 & 30 & 0.60 & 1.17 & 0.5 \\
\hline 4 & 5.0 & 11 & 5 & 3.6 & 10.00 & 100 & 3.6 & $>50$ & 100 & 2 & & & \\
\hline
\end{tabular}

* As explained in the text, these figures are based on body surface radioactivity and are only relative, semiquantitative measurements, whereas the data from rats (Table $V$ ) are quantitative.

plement fixation was determined in the usual manner (20), but employing the same rabbit serum-rat red cell system in the complement assay.

Plasma hemoglobin levels were determined by the benzidine technique (21), using the same specimens employed for measuring plasma radioactivity.

\section{RESULTS}

Anti-B. Five studies were carried out in the patient with agammaglobulinemia, and the data are presented in Table I. The chronological sequence of these experiments, involving differing ratios of antiserum/red cells, was randomized. During the four to six days prior to the injection of anti-B serum, the $\mathrm{Cr}^{51}$-labeled type $\mathrm{B}$ red cells injected into the patient were destroyed at a relatively slow, steady rate, with estimated half-survival times of from 9 to 15 days. At the time of injection of the anti-serum, from 6.9 to $11.7 \mathrm{ml}$ of red cells remained, except in the experiment involving a large dose of antiserum in which a smaller volume of cells was deliberately employed. When a very small amount of antiserum was employed so that the estimated antiserum-red cell ratio in vivo was only 0.01 , there followed a rapid disappearance of 23 per cent of the circulating red cell radioactivity, at the rate of 1.1 per cent of the injected cells per minute. There was no subsequent rise in plasma hemoglobin or $\mathrm{Cr}^{51}$. A small, definite rise in splenic radioactivity ensued, associated with a barely perceptible rise in hepatic activity. A slightly larger volume of antiserum ( $0.02 \mathrm{ml}$ per $\mathrm{ml}$ type $\mathrm{B}$ red cells), caused an acute fall of 40 per cent of the type $B$ red cells at the rate of 3.7 per cent per minute. Again there was no rise in plasma levels of hemoglobin or $\mathrm{Cr}^{51}$.
A sharp rise in splenic radioactivity and a simultaneous, somewhat smaller increase in hepatic activity were observed. The injection of $0.07 \mathrm{ml}$ of antiserum per $\mathrm{ml}$ type $\mathrm{B}$ red cells eliminated 87 per cent of the $\mathrm{Cr}^{51}$-labeled red cells from the circulation, at the rate of 13.9 per cent per minute. This was associated with a very low level of $\mathrm{Cr}^{51}$ in the plasma with no definite point of maximal activity. In this experiment both spleen and liver radioactivity increased sharply and to about the same extent. The administration of $0.5 \mathrm{ml}$ of antiserum per $\mathrm{ml}$ of type $\mathrm{B}$ red cells eliminated 100 per cent of the red cell radioactivity from the patient's circulation, at the rate of 34.7 per cent per minute. In this experiment (Figure 1) there followed a rise in plasma hemoglobin and of $\mathrm{Cr}^{51}$, the latter reaching a maximal level of 8.6 per cent of the injected dose 30 minutes after the injection of the antiserum. The rise in hepatic radioactivity was about double that over the spleen. Within two minutes of the injection of a large volume of antiserum, $10 \mathrm{ml}$ per $\mathrm{ml}$ of type $\mathrm{B}$ red cells, all of the injected $\mathrm{Cr}^{51}$ was found to be in the plasma, as was over 90 per cent of the injected red cell hemoglobin. Whereas none of the other experiments elicited symptoms from the patient, this hemolyzing dose of antiserum ${ }^{4}$ caused facial flushing to occur, beginning two minutes after injection and lasting four or five minutes. About seven minutes after the antiserum injection, pain in the groins, thighs, and low back appeared, and persisted for four or five minutes.

4 This association between intravascular hemolysis and immediate reactions to incompatible red cells has been described elsewhere (5). 
The relation between the ratio of anti-B serum/ type $B$ red cells and the relative trapping of type $B$ red cell by spleen and liver is portrayed graphically in Figure 2. The largest and frankly hemolyzing dose of antiserum is not included in this figure. For comparison the ratio of spleen/liver radioactivity after the injection of type $B$ cells into a type A subject, with approximately the same concentration of agglutinating anti-B anti- bodies but lacking anti-B hemolysins, is included. In this instance the subject's plasma volume was substituted for the volume of anti-B-containing serum.

The effects of the anti-B serum upon type B red cells in vitro is compared with its effects in vivo in Table II. The suspending and diluting medium employed in vitro was the agammaglobulinemic patient's serum. Agglutination in serum,
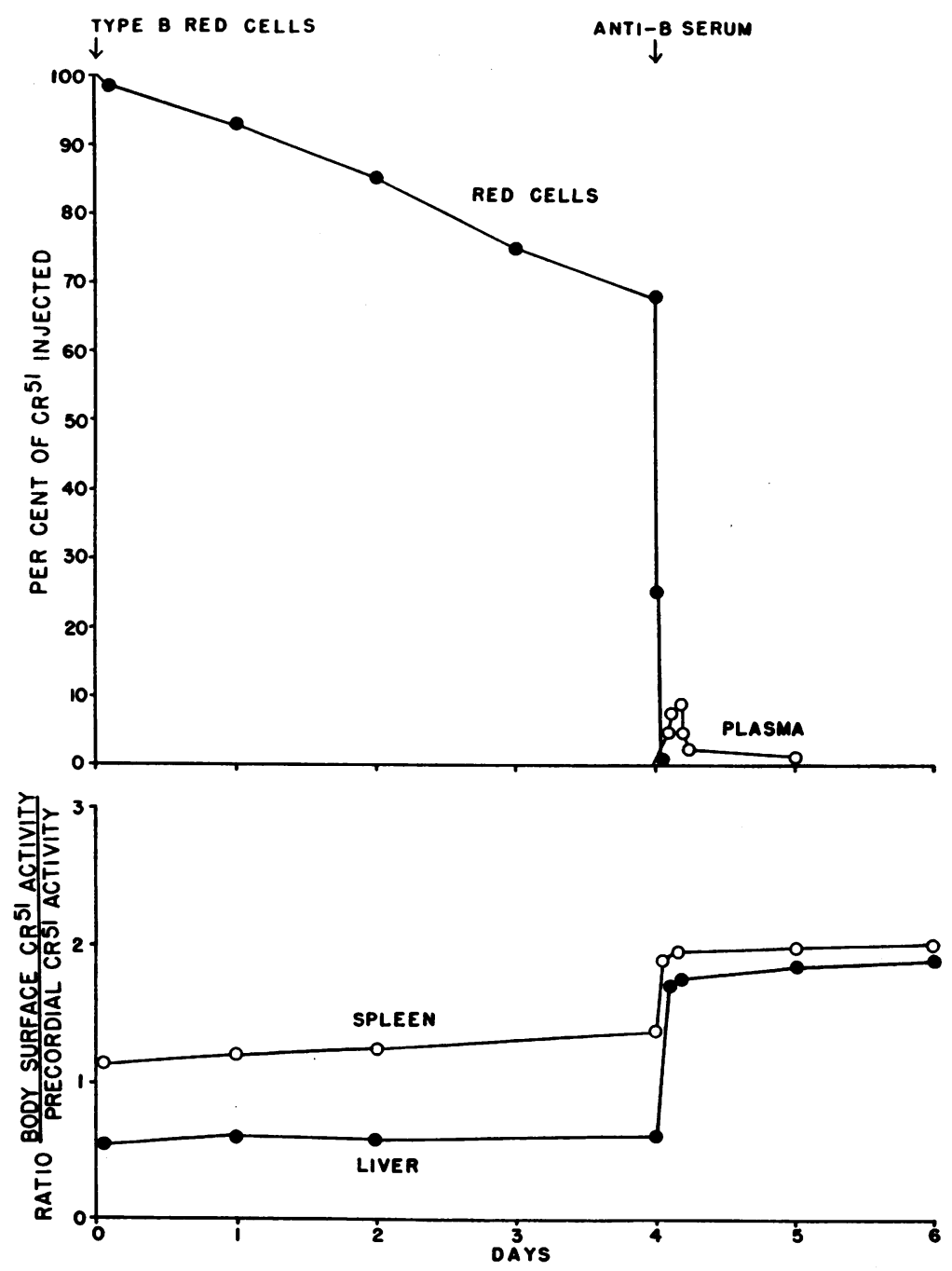

Fig. 1. EfFect of anti-B on Sequístration of type B cells in a type A patient with agammaglobulinemia. After the injection of $\mathrm{Cr}^{61}$-labeled type $B$ red cells, splenic radioactivity became somewhat elevated and increased slightly during the four days before antiserum injection. When antiserum was injected, note the abrupt fall in circulating $\mathrm{Cr}^{61}$-labeled red cells followed by a slightly delayed rise in plasma radioactivity (upper portion of figure). With the injection of anti-B, splenic radioactivity and, to an even greater extent, hepatic radioactivity sharply increased and then remained stable (lower portion). 
TABLE II

Comparison of the effects of anti-B on type $B$ red cells in vitro and in vivo

\begin{tabular}{|c|c|c|c|c|c|c|c|c|}
\hline \multirow[b]{3}{*}{ Ratio $\frac{\text { anti- } B \text { serum }}{\text { type } B \text { red cells }}$} & \multicolumn{5}{|c|}{ Effects in vitro } & \multicolumn{3}{|c|}{ Effects in vivo } \\
\hline & \multirow[b]{2}{*}{$\underset{\text { ysis }}{\text { Hemol- }}$} & \multicolumn{4}{|c|}{ Agglutination } & \multirow{2}{*}{$\begin{array}{l}\text { Intra- } \\
\text { vascular } \\
\text { hemol- } \\
\text { ysis }\end{array}$} & \multicolumn{2}{|c|}{ Sequestration } \\
\hline & & $\begin{array}{c}\text { In } \\
\text { serum }\end{array}$ & $\begin{array}{c}\text { In } \\
\text { plasma }\end{array}$ & PVP & $\begin{array}{l}\text { Coombs } \\
\text { serum }\end{array}$ & & Spleen & Liver \\
\hline $\begin{array}{r}0.01 \\
0.02 \\
0.07 \\
0.59 \\
10.00\end{array}$ & $\begin{array}{l}0 \\
0 \\
0 \\
0 \\
3+\end{array}$ & $\begin{array}{l}0 \\
0 \\
1+ \\
2+\end{array}$ & $\begin{array}{c}0 \\
1+\text { to } 2+ \\
2+\text { to } 3+\end{array}$ & $\begin{array}{l}0 \\
1+ \\
3+ \\
4+\end{array}$ & $\begin{array}{l}0 \\
\pm \\
2+ \\
4+\end{array}$ & $\begin{array}{l}0 \\
0 \\
0 \\
\pm \\
4+\end{array}$ & $\begin{array}{l}2+ \\
3+\text { to } 4+ \\
4+ \\
2+\end{array}$ & $\begin{array}{l} \pm \\
2+ \\
4+ \\
4+\end{array}$ \\
\hline
\end{tabular}

in plasma, and in PVP was assessed by suspending 1 volume of packed, antibody-treated cells in 10 volumes of the medium. The presence of "intravascular hemolysis" was judged on the basis of the appearance of hemoglobin and $\mathrm{Cr}^{51}$ in the plasma (Table I).

Anti-D. Three individual studies were conducted on three different, D-negative subjects, not immunized against the D antigen (Table III). During the four to six days prior to the injection of anti-D, $\mathrm{Cr}^{51}$-labeled type $\mathrm{D}$ red cells in these subjects appeared to survive normally, with no abnormal accumulation of radioactivity anywhere in the body. At the time of injection of the antiserum, approximately $10 \mathrm{ml}$ of circulating labeled red cells remained. When a relatively small volume of antiserum was injected, so that the ratio of antiserum/type D red cells was 0.14 , there was a delay of almost 30 minutes before an exponential decline of radioactivity commenced. The cells were then eliminated at a rate of 0.9 per cent per minute until all were gone. This was associated with a marked increase in splenic radioactivity and almost no rise in hepatic activity. A maximum of only 1.3 per cent of the injected $\mathrm{Cr}^{51}$ appeared in the plasma almost two hours after the antiserum injection. A larger dose of anti-D, 2.7 volumes of antiserum per $\mathrm{ml}$ of type $D$ red cells, caused a slightly more rapid clearance of the type D red cells so that 1.3 per cent was cleared per minute, with a maximum of 2.2 per cent of the $\mathrm{Cr}^{51}$ accumulating in the plasma 108 minutes later. In addition to a marked rise in splenic radioactivity, the hepatic activity increased moderately. With a still larger dose of anti-D, $13.34 \mathrm{ml}$ of antiserum per $\mathrm{ml}$ of type $\mathrm{D}$ red cells, the red cell clearance was at a rate of 1.8 per cent per minute and the maximal plasma $\mathrm{Cr}^{51}$ level of 4.0 per cent was reached in 95 minutes. In this study, hepatic activity was still higher, reaching almost half that of the spleen.

The relation between the ratio of volume of anti-D serum/the volume of type D red cells and the distribution between spleen and liver of trapped type D cells is depicted in Figure 2. In addition two studies are included in which $10 \mathrm{ml}$ of the same type D red cells were injected into the donor of the anti-D serum employed. In both studies the type $\mathrm{D}$ cells were cleared without delay at a rate of 3.8 per cent per minute, and a maximum of between 5 and 7 per cent of the radioactivity appeared in the plasma at about one

TABLE III

Influence of antibody-antigen ratio on the destruction of $C r^{51}$-labeled type $D$ red cells by anti-D in passively immunized D-negative subjects

\begin{tabular}{|c|c|c|c|c|c|c|c|c|c|c|c|c|}
\hline \multirow{3}{*}{$\begin{array}{c}\text { Initial } \\
\text { volume }\end{array}$} & \multirow{3}{*}{$\begin{array}{c}\text { Initial } \\
\text { half- } \\
\text { survival } \\
\text { time }\end{array}$} & \multicolumn{3}{|c|}{ Antiserum injected } & \multicolumn{8}{|c|}{ Effect of antiserum in vivo } \\
\hline & & \multirow{2}{*}{$\begin{array}{l}\text { Days } \\
\text { after } \\
\text { red } \\
\text { cell } \\
\text { injec- } \\
\text { tion }\end{array}$} & \multirow{2}{*}{$\begin{array}{c}\text { Volume } \\
\text { red } \\
\text { cells } \\
\text { present }\end{array}$} & \multirow{2}{*}{$\begin{array}{c}\text { Ratio } \\
\text { anti- } \\
\text { serum/ } \\
\text { red } \\
\text { cells }\end{array}$} & \multicolumn{3}{|c|}{ Red cell destruction } & \multicolumn{2}{|c|}{$\underset{\text { plasma } C r^{51}}{\text { Maximum }}$} & \multicolumn{3}{|c|}{$\begin{array}{l}\text { Sites of red cell } \\
\text { sequestration }\end{array}$} \\
\hline & & & & & & & Rate & $\begin{array}{c}\text { Per cent } \\
\mathrm{Cr}^{51} \\
\text { injected }\end{array}$ & $\begin{array}{l}\text { Peak } \\
\text { time }\end{array}$ & $\Delta \mathrm{S}$ & $\Delta \mathrm{L}$ & $\overline{S / L}$ \\
\hline$m l$ & days & & $m l$ & & $\%$ & $m l$ & $\% / \min$ & & $\min$ & & & \\
\hline 11.2 & 30 & 6 & 9.8 & 0.14 & 100 & 9.8 & 0.9 & 1.3 & 114 & 5.00 & 0.10 & 50 \\
\hline 11.5 & 28 & 4 & 10.4 & 2.70 & 100 & 10.4 & 1.3 & 2.2 & 108 & 3.78 & 1.07 & 3.5 \\
\hline 10.5 & 25 & 4 & 9.0 & 13.34 & 100 & 9.0 & 1.8 & 4.0 & 95 & 4.6 & 2.2 & 2.1 \\
\hline
\end{tabular}




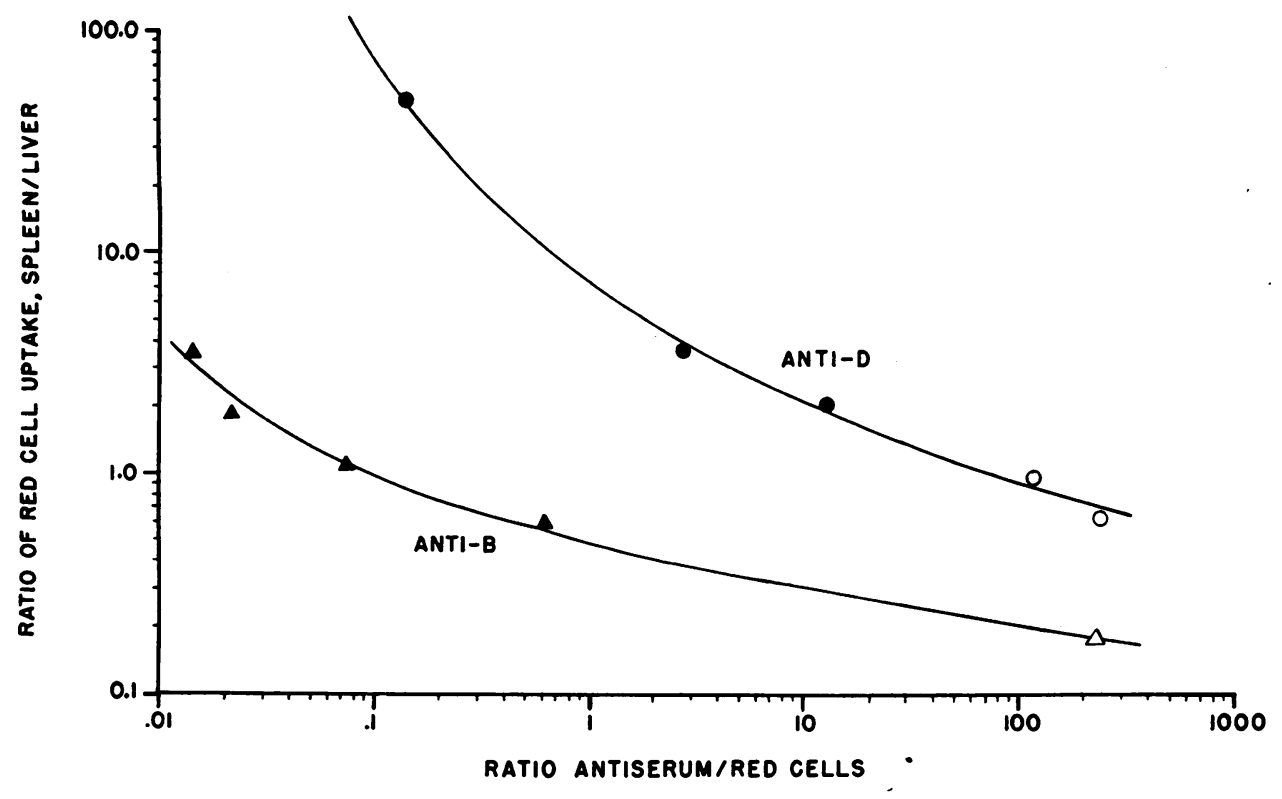

Fig. 2. Quantitative comparison of THE ABILITy OF ANTI-B AND ANTI-D ANTIBodies to CAUSE SPLENIC OR HEPATIC SEQUESTRATION OF RED CELLS. In a patient with agammaglobulinemia given extremely small amounts of anti-B serum (black triangles) the relative trapping of $\mathrm{Cr}^{31}$ labeled type $B$ red cells by spleen and liver resembled that produced by very large (several hundred times as much) amounts of anti-D serum with type D cells (black circles). The distribution of type $B$ red cells injected into a type $A$ recipient whose serum contained nonhemolyzing autogenous antibodies and an anti-B agglutinin titer comparable to that of the anti-B serum employed is depicted by the white triangles. The distribution of type $\mathrm{D}$ red cells injected on two different occasions into the D-negative donor of the anti-D serum employed above, is represented by the white circles. A log-log plot has been used.

hour. In the first study the hepatic $\mathrm{Cr}^{51}$ uptake slightly exceeded that of the spleen $(\mathrm{S} / \mathrm{P}=$ $0.90)$; in the other the $\mathrm{S} / \mathrm{P}$ ratio was only 0.65 . One of these studies was included in a previous report (2).

The effects of the anti-D serum used upon the type $\mathrm{D}$ red cells employed in these studies in vitro and in vivo are presented in Table IV. Normal serum was used as a suspending and diluting medium in all titrations.

Rabbit antibodies against rat red cells. The effect of adding to rat red cells various amounts of rabbit antiserum developed against rat red cells, upon their subsequent survival in vivo, is presented in Table V. In none except the highest of the concentrations employed was there significant intravascular hemolysis, as judged by the uniformly low levels of radioactivity in the plasma and kidneys (15). The survival of the labeled red cells was curtailed in direct proportion to the amount of antibody employed. With relatively small amounts of antibody $(0.17$ to $0.33 \mathrm{ml} \mathrm{rab-}$

TABLE IV

Comparison of the effects of anti-D on type $D$ red cells in vitro and in vivo

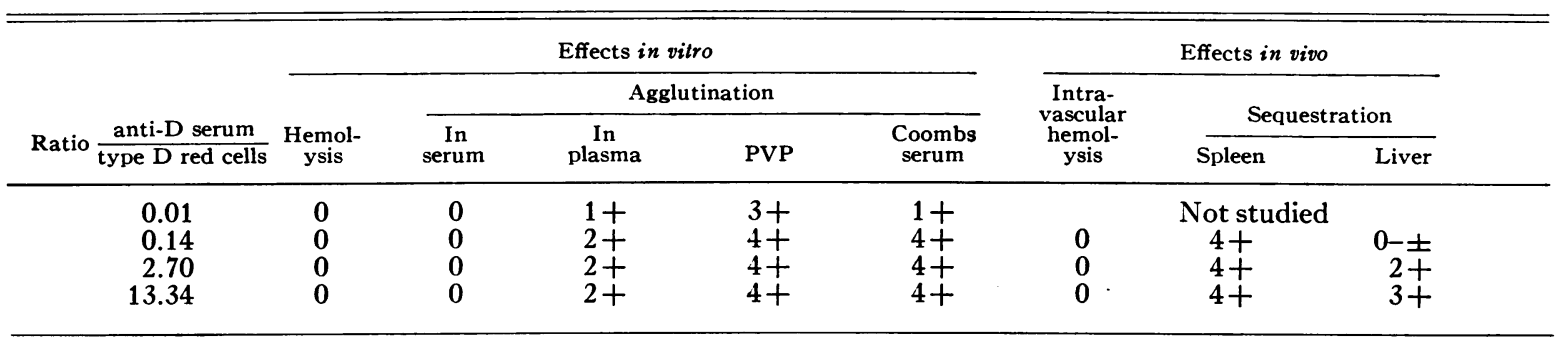


bit antiserum per $\mathrm{ml}$ rat red cells), the red cells were incompletely and relatively slowly destroyed and the spleen was the dominant sequestering organ. At higher antiserum concentrations, however, in linear proportion to the quantity of antibody employed, trapping by the liver predominated (upper portion of Figure 3). As portrayed in the lower part of Figure 3, this preemption by the liver of red cell trapping at high antibody doses was due to the tendency of this relatively massive organ to approach (but not to exceed) the spleen in trapping ability on a gramfor-gram basis. Figure 4 illustrates the fact that the sequestering activity of the spleen relative to that of the liver declined in linear proportion to the amount of antibody employed.

In Table $\mathrm{V}$ the effects of the rabbit serum antibody employed upon rat red cells in vitro are compared with those observed in vivo. Analogous to the human studies, titrations were carried out in a normal fresh rat serum medium. It is apparent from Table $\mathrm{V}$ that even large amounts of

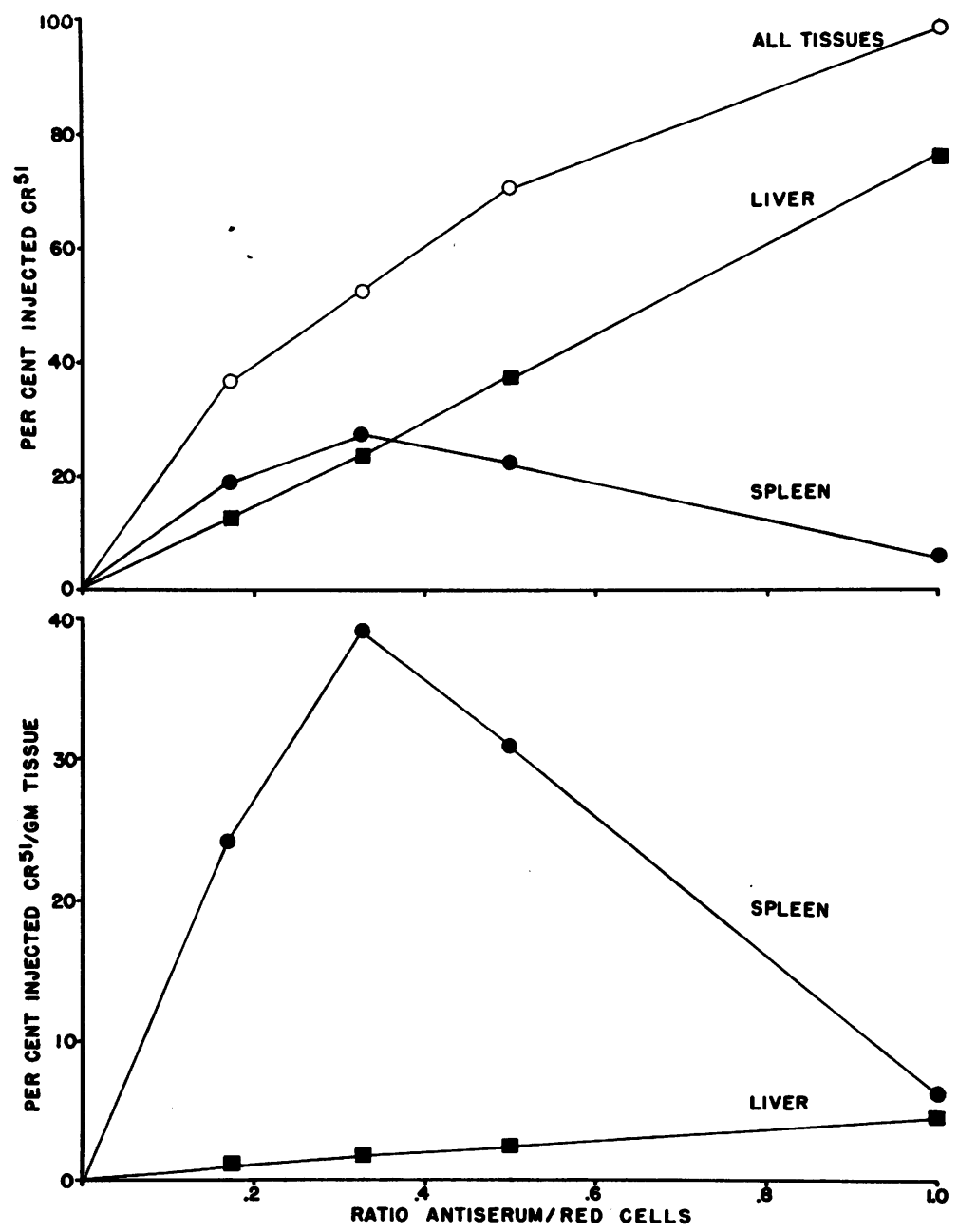

Fig. 3. THE EFFECT OF VARIOUS ANTIBODY/ANTIGEN RATIOS ON THE SEQUESTRATION IN VIVO OF RAT RED CELLS PREVIOUSLY TREATED IN VITRO WITH RABBIT ANTI-RAT RED CELL SERUM. In the upper portion of the figure it is evident that the total sequestration of $\mathrm{Cr}^{51}$-labeled red cells ("all tissues") increased in proportion to the antiserum/red cell ratio. The total splenic uptake of $\mathrm{Cr}^{51}$ reached a maximum at an antiserum/red cell ratio of 0.33 , when its ability to trap red cells was over 20 times that of the liver, on a gram-for-gram basis (lower portion). With larger amounts of antibody, the spleen and liver approximated each other in trapping ability per gram tissue (lower portion), and therefore the total liver uptake predominated. 


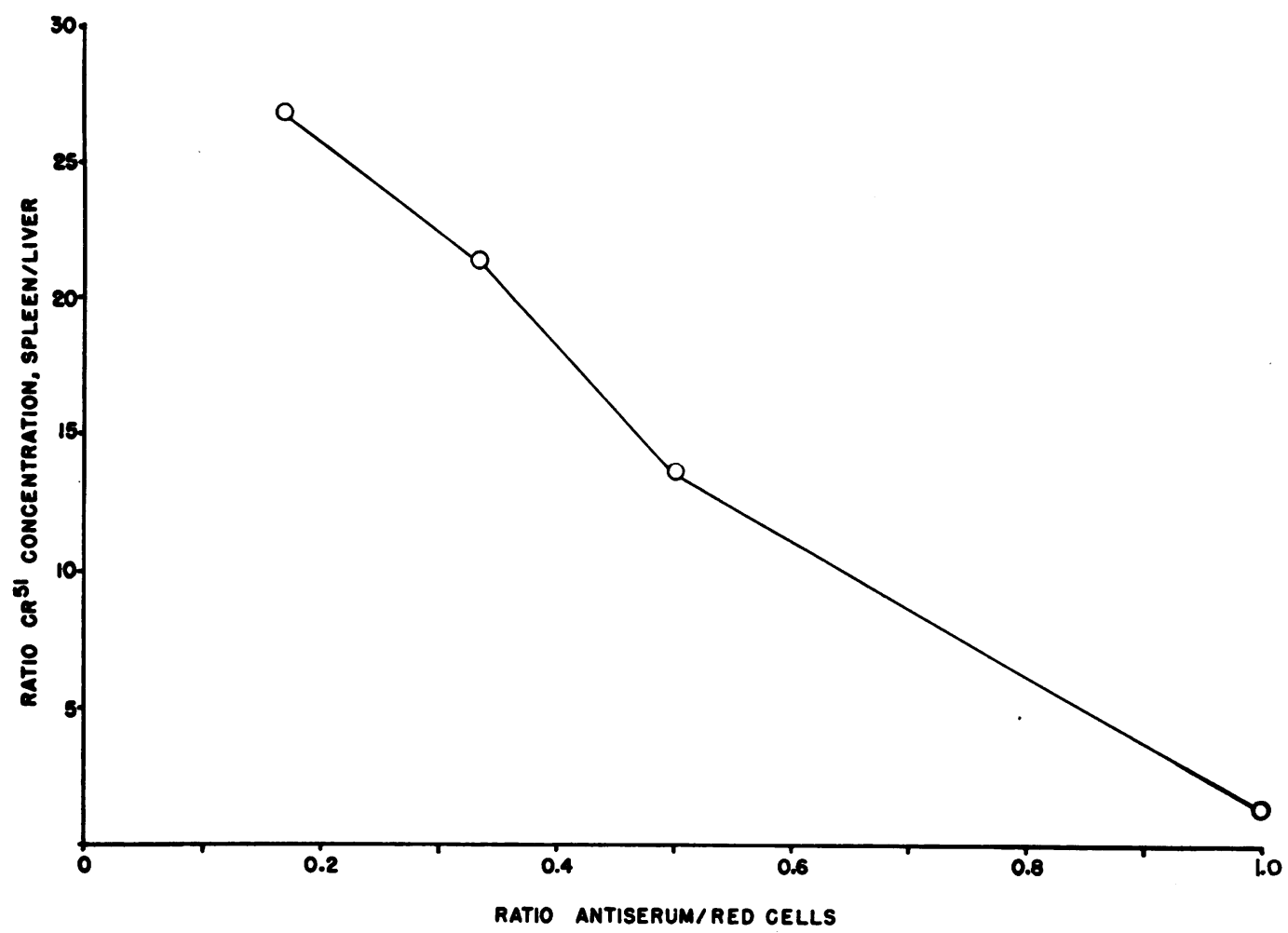

Fig. 4. Relationship between antibody/ANtigen Ratios and THE SPleEn/Liver Ratios in Rats. Replotting the data from the lower portion of Figure 3 reveals that the extent of sequestration of antibody-treated, $\mathrm{Cr}^{51}$-labeled, red cells by the spleen relative to the liver bears an inverse relationship to the amount of antibody present.

this antibody failed to provoke any red cell sequestration in the lungs or femur. The very low levels of radioactivity in the lungs correlated with the levels of activity remaining in the peripheral blood. Only when there was some evidence of intravascular hemolysis, as indicated by plasma radioactivity, was there any appreciable kidney radioactivity.

\section{DISCUSSION}

In general these studies support previous observations $(1,2)$ to the effect that antibodies which bind to red cells without agglutinating or hemolyzing them may cause a predominant trapping of the cells by the spleen. It is clear, however, that this pattern is affected by quantitative factors. Thus in the experiments with anti-D,

TABLE V

The effects of rabbit anti-rat red cell serum in vitro and in vivo

\begin{tabular}{|c|c|c|c|c|c|c|c|c|c|c|c|c|c|c|}
\hline \multirow{4}{*}{$\begin{array}{l}\text { No. } \\
\text { of } \\
\text { rats }\end{array}$} & \multirow{4}{*}{ Ratio } & \multicolumn{3}{|c|}{ Effects in vitro } & \multicolumn{10}{|c|}{ Effects in vivo } \\
\hline & & \multirow[b]{3}{*}{ Hemolysis } & \multirow{2}{*}{\multicolumn{2}{|c|}{ Agglutination }} & \multicolumn{3}{|c|}{ Red cell destruction } & \multicolumn{7}{|c|}{$\mathrm{Cr}^{51}$ uptake } \\
\hline & & & & & \multirow{2}{*}{$\begin{array}{l}\text { Per cent } \\
\text { destroyed } \\
\text { in } 2 \mathrm{hrs}\end{array}$} & \multirow[b]{2}{*}{ Rate } & \multirow{2}{*}{$\begin{array}{c}\text { Intra- } \\
\text { vascular } \\
\text { hemolysis }\end{array}$} & \multicolumn{2}{|c|}{ Spleen } & \multicolumn{2}{|c|}{ Liver } & \multirow{2}{*}{$\begin{array}{c}\text { Lungs } \\
\text { Total }\end{array}$} & \multirow{2}{*}{$\begin{array}{c}\text { Femur } \\
\text { Total }\end{array}$} & \multirow{2}{*}{$\underset{\text { Total }}{\text { Kidney }}$} \\
\hline & & & serum & PVP & & & & & Total & & Total & & & \\
\hline & & & & & & $\% / \min$ & & $\% / g$ & $\%$ & $\% / g$ & $\%$ & $\%$ & $\%$ & $\%$ \\
\hline $\begin{array}{l}2 \\
2 \\
8 \\
2 \\
2\end{array}$ & $\begin{array}{l}0.17 \\
0.33 \\
0.50 \\
1.0 \\
2.0\end{array}$ & $\begin{array}{c}\mathbf{0} \\
\mathbf{0} \\
\mathbf{0} \\
\pm \\
\mathbf{1}+\end{array}$ & $\begin{array}{l}0 \\
1+ \\
2+ \\
3+ \\
4+\end{array}$ & $\begin{array}{l}3+ \\
4+ \\
4+ \\
4+ \\
4+\end{array}$ & $\begin{array}{l}37.0 \\
52.5 \\
70.4 \\
98.7 \\
97.0\end{array}$ & $\begin{array}{r}1.1 \\
1.9 \\
4.3 \\
34.6 \\
34.6\end{array}$ & $\begin{array}{l}0 \\
0 \\
0 \\
\pm \\
2+\end{array}$ & $\begin{array}{r}24.1 \\
38.9 \\
30.9 \\
6.3 \\
10.8\end{array}$ & $\begin{array}{r}18.8 \\
27.2 \\
22.4 \\
6.1 \\
12.2\end{array}$ & $\begin{array}{l}0.9 \\
1.8 \\
2.3 \\
4.8 \\
2.9\end{array}$ & $\begin{array}{l}12.4 \\
24.4 \\
37.6 \\
76.5 \\
49.6\end{array}$ & $\begin{array}{l}0.6 \\
0.5 \\
0.3 \\
0.1 \\
0.3\end{array}$ & $\begin{array}{l}0.1 \\
0.1 \\
0.1 \\
0.1 \\
0.2\end{array}$ & $\begin{array}{l}0.5 \\
0.5 \\
0.4 \\
1.3 \\
3.7\end{array}$ \\
\hline
\end{tabular}


an incomplete antibody, relatively small amounts of antibody produced a slow and quite selective splenic pattern of destruction, while increasing the amount of circulating antibody quickened the rate of sequestration and evoked sequestration by the liver as well. By extrapolation, as shown in Figure 2, it appears probable that the tendency of some highly immunized subjects to trap type $D$ red cells in the liver as well as, or even somewhat better than, in the spleen may reflect an extreme limit of this quantitative relationship. Thus the anti-D type of incomplete agglutinin may be considered to possess a certain range of effect on red cells, varying from a purely splenic sequestration, when small to moderately large amounts of antibody are involved, to a partially hepatic mechanism when very large amounts are present.

The studies with anti-B, an agglutinating, complement-fixing, potentially lytic antibody, indicated that it, too, had a spectrum of activity in vivo, ranging in its effects, when given in nonlytic doses, from a predominantly splenic to a strongly hepatic pattern of sequestration. With this antibody, however, splenic sequestration was less active than with anti-D, occurred over a rather narrow range of antibody/antigen proportion, and was selective only at barely injurious antibody concentrations which were, indeed, undetectable by their effects in vitro: ${ }^{5}$ With small to moderate amounts of such antibody, a tendency for hepatic trapping to occur is manifest and predominates over a wide range of antibody-antigen ratios, until actual intravascular hemolysis is encountered. As shown in Figure 2 this relationship can be extrapolated to include, at the extreme, data on the actively immunized subject whose plasma contained a relative infinity of nonhemolytic agglutinating anti-B antibody. The spectrum of action in vivo of the potentially lytic and agglutinating antibody (anti-B), may, through quantitative variation, overlap the spectrum of action of the in-

\footnotetext{
5 Presumably the lowest anti-B level was provided by the patient with agammaglobulinemia herself, prior to the present studies, when, despite lack of detectable antibody in vitro, she sequestered type B cells slowly, over several days, in the spleen. That splenic sequestration of normal red cells on an immune basis may occur despite the absence of incompatibility in vitro has been previously reported (22) and confirmed $(23,24)$.
}

complete agglutinin (anti-D). On the other hand, if one may assume that the antibody concentration (anti-D or anti-B) in these hyperimmune sera differs by only a fewfold, it can be estimated from Figure 2 that several hundred times as much anti-D is required to mimic a given, small amount of anti-B in its effects in vivo.

With the volume of red cells employed, trapping by anti-D always led to a small, but detectable, rise in plasma $\mathrm{Cr}^{51}$ and hemoglobin, as previously reported (2). Similarly the hepatic sequestration of $5.1 \mathrm{ml}$ of type $\mathrm{B}$ red cells by anti-B led to a delayed rise in plasma $\mathrm{Cr}^{51}$ and hemoglobin, reaching a peak 30 minutes after antiserum injection. On the other hand, the sequestration of 5.9 and $6.0 \mathrm{ml}$ of red cells by smaller amounts of anti-B antibody in Experiments 5 and 2, respectively, caused essentially no rise in plasma hemoglobin, although the rate of sequestration was rapid (as compared to anti-D) and the sequestration was permanent. A similar absence of plasma hemoglobin despite rapid, permanent sequestration, has been observed with autogenous red cells previously incubated at $37^{\circ} \mathrm{C}$ for 48 hours (5). Therefore, contrary to previous deductions (2), it may be that any significant rise in plasma hemoglobin during immune hemolysis may reflect the action of complement or complement-like intravascular substances.

The studies in rats involved the use of a heterologous antiserum, which after heating contained only a small amount of lytic antibody (even in the presence of large volumes of fresh rat serum), a moderate concentration of agglutinin, and a high concentration of an incomplete agglutinin. The pattern of destruction in vivo of red cells pretreated with such antiserum in vitro was markedly influenced by the quantity of the antiserum employed. Thus, small amounts of antibody, sufficient to destroy only partially the treated red cells, caused a slow ( 1.1 per cent per minute), predominantly splenic trapping. As larger and larger amounts of antibody were employed, the liver, in direct linear proportion, assumed the greater role. Thus, at a serum/red cell ratio of 1.0 , the liver accounted for about 80 per cent of the sequestered red cells, and, as in the anti-B experiments, a red cell clearance rate of about 35 per cent per minute was attained. It is apparent from an examination of Figure 3 and Table 
IV that the liver assumed the major role in red cell destruction by pre-emption rather than by simply receiving the overflow from a "saturated" spleen. Finally, with large, lytic volumes of antiserum actual intravascular hemolysis was evident and radioactivity, presumably radioactive hemoglobin, accumulated for the first time in the kidney. This spectrum of hemolytic activity of rabbit antibody in rats closely paralleled that of anti-B in man (compare Tables I and V). Thus, in these studies in rats the same antibody, or mixture of antibodies, was capable of causing three distinct patterns of hemolysis: 1) a slow, incomplete trapping of red cells in the spleen; 2) a rapid, complete sequestration, chiefly in the liver; and 3) an intravascular lysis with deposition of hemoglobin throughout the reticuloendothelial system and with spillage into the kidneys. Although previous studies in dogs had indicated that red cells coarsely agglutinated by metallic cations may lodge in the lungs (2), in the present studies the lungs were devoid of red cell trapping activity, regardless of the intensity of agglutination of the injected red cells; nor was there evidence of hemoglobin uptake by the lungs. Furthermore, pulmonary sequestration of red cells, apart from extravasations into the alveoli, as in essential pulmonary hemosiderosis (25), has not been observed experimentally or clinically in man. Thus it appears that the reticuloendothelial tissue of the lungs seldom, if ever, participates in hemolytic mechanisms.

The mechanisms by which antibody-injured red cells are sequestered are still in doubt. There is reasonably good, but necessarily indirect, evidence that incomplete agglutinins destroy red cells by rendering them agglutinable in the presence of fibrinogen and other anisometric macromolecules in vivo $(2,18)$, which in turn leads to their low pressure filtration (26) by the spleen. Although it has been postulated that frankly agglutinating antibodies, such as anti-B, cause hepatic trapping by causing large, firm agglutinates which are also filterable by the relatively large liver sinusoids (2), the extensive, comparative studies of human iso-antibodies by Cutbush and Mollison (12, 13, 27 ) indicate that those antibodies which bind complement, without producing frank agglutination in vitro, also cause a rapid (probably hepatic) pattern of red cell destruction. Thus, in the present studies, some hepatic sequestration was observed at antibody concentrations which caused little or no agglutination in vitro. However, hepatic uptake of red cells was not pronounced until agglutinating amounts of antibody were employed. It appears that the liver may partially participate in red cell trapping, in a "spleen-like" fashion, either in the splenectomized subject (2) or in the presence of a vast excess of incomplete agglutinin, but that a purely hepatic pattern of destruction usually commences with, or is coincident with, actual red cell agglutination demonstrable in vitro. Whether the prime mechanism of hepatic sequestration involves a simple physical filtration of lattice-forming red cell agglutinates (26), possibly involving "uncoated" red cells (28), or a surface adherence to fixed macrophages, is yet to be determined.

\section{SUMMARY}

The influence of antibody/antigen proportions on the kinetics of red cell destruction were studied in man and in rats.

The effects of anti-B iso-antibody were studied by passively immunizing an agammaglobulinemic patient with various amounts of anti-B serum and observing the pattern of destruction of a given amount of type $B$ red cells. A spectrum of effects was observed, ranging from a slow partial trapping by the spleen with small doses to a brisk hepatic trapping with large doses, while still larger doses caused intravascular hemolysis.

The effects of incomplete anti-D iso-antibody were studied by passively immunizing each of several D-negative subjects with various amounts of anti-D serum and observing their effect upon given amounts of type $\mathrm{D}$ red cells. Although small and moderate amounts of antibody caused a mainly splenic pattern of destruction, large amounts caused a moderate hepatic uptake and were similar in their effects to very small amounts of anti-B antibody.

Studies on rats employing a rabbit antibody against rat red cells indicated a spectrum of action similar to that of anti-B in man: a slow, incomplete sequestration by the spleen occurred when small amounts of antibody were employed; a rapid, largely hepatic sequestration occurred with larger amounts; and with still larger amounts, intravascular lysis was seen, with hemoglobin 
deposition in the liver, spleen and kidney. The lungs and bone marrow did not participate in the sequestration process at any dose of antibody.

Although the kinetics of red cell destruction in vivo by complete and by incomplete agglutinins ordinarily differ, the differences are modified by purely quantitative factors.

\section{REFERENCES}

1. Jandl, J. H. Sequestration by the spleen of red cells sensitized with incomplete antibody and with metallo-protein complexes (abstract). J. clin. Invest. 1955, 34, 912.

2. Jandl, J. H., Jones, A. R., and Castle, W. B. The destruction of red cells by antibodies in man. I. Observations on the sequestration and lysis of red cells altered by immune mechanisms. J. clin. Invest. 1957, 36, 1428.

3. Jandl, J. H., and Simmons, R. L. The agglutination and sensitization of red cells by metallic cations: Interactions between multivalent metals and the red-cell membrane. Brit. J. Haemat. 1957, 3, 19.

4. Harris, I. M., McAlister, J. M., and Prankerd, T. A. J. The relationship of abnormal red cells to the normal spleen. Clin. Sci. 1957, 16, 223.

5. Jandl, J. H., and Tomlinson, A. S. The destruction of red cells by antibodies in man. II. Pyrogenic, leukocytic and dermal responses to immune hemolysis. J. clin. Invest. 1958, 37, 1202.

6. Berendes, M. The proportion of reticulocytes in the erythrocytes of the spleen as compared with those of circulating blood, with special reference to hemolytic states. Blood 1959, 14, 558.

7. Jandl, J. H. The agglutination and sequestration of immature red cells. J. Lab. clin. Med. 1960, 55, 663.

8. Cruz, W. O. Acetylphenylhydrazine anemia. 1. The mechanism of erythrocyte destruction and regeneration. Amer. J. med. Sci. 1941, 202, 781.

9. Hughes-Jones, N. C., Mollison, P. L., and Veall, N. Removal of incompatible red cells by the spleen. Brit. J. Haemat. 1957, 3, 125.

10. Motulsky, A. G., Casserd, F., Giblett, E. R., Broun, G. O., Jr., and Finch, C. A. Anemia and the spleen. New Engl. J. Med. 1958, 259, 1164.

11. Harris, I. M., McAlister, J., and Prankerd, T. A. J. Splenomegaly and the circulating red cell. Brit. J. Haemat. 1958, 4, 97.

12. Cutbush, M., and Mollison, P. L. Relation between characteristics of blood-group antibodies in vitro and associated patterns of red-cell destruction in vivo. Brit. J. Haemat. 1958, 4, 115.

13. Mollison, P. L. Blood-group antibodies and redcell destruction. Brit. med. J. 1959, 2, 1123.

14. Biozzi, G., Benacerraf, B., and Halpern, B. N. Quantitative study of the granulopectic activity of the reticulo-endothelial system. II. A study of the kinetics of the granulopectic activity of the R. E. S. in relation to the dose of carbon injected. Relationship between the weight of the organs and their activity. Brit. J. exp. Path. 1953, 34, 441.

15. Kaplan, M. E., Schwartz, E., Weiss, L., and Jandl, J. H. Unpublished observations.

16. Chaplin, H., Jr. Studies on the survival of incompatible cells in patients with hypogammaglobulinemia. Blood 1959, 14, 24.

17. Jandl, J. H., Greenberg, M. S., Yonemoto, R. H., and Castle, W. B. Clinical determination of the sites of red cell sequestration in hemolytic anemias. J. clin. Invest. 1956, 35, 842.

18. Jandl, J. H., and Castle, W. B. Agglutination of sensitized red cells by large anisometric molecules. J. Lab. clin. Med. 1956, 47, 669.

19. Coombs, R. R. A., Mourant, A. E., and Race, R. R. A new test for the detection of weak and "incomplete" Rh-agglutinins. Brit. J. exp. Path. 1945, $26,255$.

20. Kabat, E. A., and Mayer, M. M. Experimental Immunochemistry. Springfield, Ill., Charles C Thomas, 1948.

21. Ham, T. H. A Syllabus of Laboratory Examination in Clinical Diagnosis. Cambridge, Mass., Harvard University Press, 1950.

22. Jandl, J. H., and Greenberg, M. S. The selective destruction of transfused "compatible" normal red cells in two patients with splenomegaly. J. Lab. clin. Med. 1957, 49, 233.

23. Fudenberg, H., and Allen, F. H., Jr. Transfusion reactions in the absence of demonstrable incompatibility. New Engl. J. Med. 1957, 256, 1180.

24. Adner, P. L., and Sjölin, S. Unexpected blood group incompatibility, revealed by ${ }^{51} \mathrm{Cr}$-labelled red cells. Scand. J. clin. Lab. Invest. 1957, 9, 265.

25. Jonsson, B., Vahlquist, B., and Agner, K. Essential hemosiderosis. Blood 1951, 6, 665.

26. Jandl, J. H. Sequestration of reticulocytes and of abnormal red cells by filtration at low pressures (abstract). J. clin. Invest. 1958, 37, 905.

27. Mollison, P. L., and Cutbush, M. Use of isotopelabelled red cells to demonstrate incompatibility in vivo. Lancet $1955,1,1290$.

28. Jones, A. R., and Kaneb, L. A new property of isoagglutinins of the ABO blood group system. Blood 1959, 14, 1094. 